\title{
USE OF BACTERIA AND YEAST STRAINS FOR DAIRY WASTEWATER TREATMENT
}

\author{
C Keffala ${ }^{1}$, F Zouhir ${ }^{2}$, K Ben Hadj Abdallah ${ }^{3}$, S Kammoun $^{4}$ \\ ${ }^{1}$ Laboratoire de microbiologie, Institut Supérieur Agronomique de Chott Mariem, BP 47, 4042 (Sousse), Tunisie \\ ${ }^{2}$ Université de Liège, Unité Assainissement et Environnement, 185 Avenue de Longwy, B6700 Arlon, Belgium. \\ ${ }^{3}$ Laboratoire de microbiologie, Institut Supérieur Agronomique de Chott Mariem, BP 47, 4042 (Sousse), Tunisie \\ ${ }^{4}$ Laboratoire de microbiologie, Institut Supérieur Agronomique de Chott Mariem, BP 47, 4042 (Sousse), Tunisie
}

\begin{abstract}
The present investigation was carried out to study the biodegradation of dairy effluent collected from a regional dairy industry, in Tunisia, by using selected aerobic microbial and yeast isolates. The predominant microorganisms: Candida albicans, Candida krusei, Lactobacillus plantarum and Lactobacillus casei isolated from activated sludge pond of the dairy plant were used. Biodegradation tests were performed in batch into Erlenmeyer flasks containing collected dairy wastewater samples. Two sets of experiments were carried out in duplicate. For the first set of experiments, each bacteria and yeast strain was used for the preparation of four inoculums composed of single culture. These inoculums are added separately in the test samples with a concentration of $1 \%(\mathrm{v} / \mathrm{v})$. For the second set of experiments, three inoculums rate $(1,5$ and $10 \%(\mathrm{v} / \mathrm{v}))$ were tested. A bacteria and yeast mixed culture were added separately in the test samples.A variable amount of COD, proteins and total sugars reduction was observed with individual and mixture isolates after 25 days treatment period. The chemical oxygen demand (COD) has received reduction varying between 51.6 and $71.6 \%$ with individual isolates at $1 \%(\mathrm{v} / \mathrm{v})$ inoculum rate, while bacterial mixed culture and yeast mixed culture showed reduction up to 75.8 and $70.7 \%$, respectively, at $1 \%(v / v)$ inoculum rate. Isolates with inoculum rate of $5 \%(\mathrm{v} / \mathrm{v})$ proved to be most efficient in the treatment of effluent. The highest reduction of total sugar content was obtained by yeast consortium while the highest reduction of protein content was obtained by bacteria consortium.
\end{abstract}

Keywords: Bio-augmentation, Dairy wastewaters, Proteins, Sugar, Chemical oxygen demand ****

\section{INTRODUCTION}

The wastewater treatment is today, a major concern of the industries which are subjected to an increasingly rigorous regulation. In the case of dairy industry, this one consumes much water during the manufacturing of the dairy products including buttermilk and whey; thus leading to produce a huge quantity of wastewaters rich in organic matter. In Tunisia, it has been reported that the dairy industry generates 6 liters of wastewater per liter of processed milk and 115 liters of wastewater per $\mathrm{kg}$ of whey. The dairy effluent contains 10 to $15 \%$ more organic matter than domestic wastewater and thus constitutes a major risk when it is discharged without suitable treatment [1].

Although the dairy wastewater polluting load is highly variable, the composition of these effluents is generally close to that of diluted milk with COD concentration in the range of 2 and $7 \mathrm{~g} / \mathrm{l}$, a COD/BOD ratio ranging between 1.5 and 2 and BOD/NTK/P ratio of about 100/6/4 [2].

Given the composition of dairy effluents, biological wastewater treatment with activated sludge process is the most suitable [3]. However, dysfunctions of conventional wastewater treatment plant (activated sludge) due to the variation of the pollutant load as well as the production of excess sludge are counted as negative points and lead the scientists to seek for methods combining both the improvement of the treatment efficiency and the reduction of the sludge production. A viable alternative is bioaugmentation strategies, such as the addition of external microorganisms with high capacity for the degradation of a specific substrate.

The process of seeding inoculation of microorganisms for degrading organic materials has rapidly become an increasing practice in many countries because it is economical and its application is uncomplicated.

The present investigation was carried out to evaluate the bioremediation of dairy effluent of Tunisian dairy plant. For this purpose, predominant microorganisms were isolated from dairy plant to test their ability to degrade organic matter and to evaluate their effects on the removal of COD, proteins and total sugars.

\section{MATERIALS AND METHODS}

\subsection{Sampling}

The raw dairy wastewater samples were gained from a regional dairy industry, Sidi Bou Ali District Milk producer's in Tunisia. The effluent treatment plant located in the dairy industry based on activated sludge process has a capacity to treat $1500 \mathrm{~m} 3 /$ day of wastewater and was designed to meet the discharge standards. A monitoring program with regularly scheduled weekly sampling was adopted during three months: March, April, and May. Every 
week, the untreated dairy wastewater samples of one liter were collected at intervals of one hour for a sampling period of 7 hours. The composite sample was obtained at the end of the sampling period and then was stored in the refrigerator at $4{ }^{\circ} \mathrm{C}$, until the analysis was carried out. However, for the microbial study, activated sludge samples were collected during aeration period from activated sludge pond of the dairy industry to isolate the predominant microorganisms which would be used for biodegradation batch tests.

\subsection{Dairy Waste Water Samples Characterization}

The characteristics of untreated dairy wastewater effluent were analyzed according to Standard methods [4] in order to obtain the information regarding the general characteristics of the dairy effluents. The following tests were performed: $\mathrm{pH}$, chemical oxygen demand (COD), biochemical oxygen demand (BOD), fatty material, electrical conductivity (EC), Chlorides and suspended solids (SS).

\subsection{Isolation and Identification of Bacteria and}

\section{Yeast Strains}

The isolation and identification of bacteria and yeast strains were done as described by Samet - Bali et al. [5].From samples collected within activated sludge pond, ten milliliter was inoculated in two Erlenmeyer flasks. The first one contains $90 \mathrm{ml}$ of Nutrient Broth (Bio-rad, France) media and the second one contains $90 \mathrm{ml}$ of Sabouraud Broth (Biorad, France). The flasks were kept on rotary shaker at room temperature for 24-48 h. For the isolation and identification of bacteria strains, one loopful enriched sample from Nutrient Broth flask was streaked on MRS Agar (de Man, Rogosa and Sharpe) (Bio-rad, France) and then incubated at $37^{\circ} \mathrm{C}$ for 48 hours. Two predominant colonies differing in morphological peculiarities and Gram's straining were isolated in pure form and maintained on slopes of MRS agar slants at $4^{\circ} \mathrm{C}$. The two strains were cultivated on MRS Agar petri plates at $37^{\circ} \mathrm{C}$ for 48 hours. Biochemical characteristics were studied using Api 20C kits (Bio-Merieux) and the results were integrated using API Web software. For the isolation and identification of yeast strains, one loopful enriched sample from Sabouraud Broth was streaked on Chromagar Candida plate (Chromagar, France) and incubated for 48 hours at $37^{\circ} \mathrm{C}$. Two pure forms of yeast were obtained after successive transfer of individual colony in Sabouraud Chloramphenicol Agar (Bio-rad, Marnes LaCoquette, France) incubated at $30^{\circ} \mathrm{C}$ for 48 hours and the identification of Candida species was based on macroscopic characteristics of colonies, Gram's staining and the color of colonies on chromagar Candida. Strains were stored at $4^{\circ} \mathrm{C}$ on Sabouraud dextrose broth (Bio-rad, France) supplemented with glycerol at $10 \%(\mathrm{v} / \mathrm{v})$. Biochemical characteristics were studied using Api Candida kits (BioMerieux).

\subsection{Inoculum Preparation}

To study the biodegradation efficiency of the microbial and yeast isolates, biomass of actively growing cells was prepared as described by Porwal et al. [6]. Each bacterial strain was inoculated to $50 \mathrm{ml}$ MRS broth medium and incubated at $37^{\circ} \mathrm{C}$ for 24 hours with $150 \mathrm{rpm}$ agitation speed. For the preparation of yeast inoculum, each yeast strain was inoculated to $50 \mathrm{ml}$ Sabouraud medium and incubated at $30^{\circ} \mathrm{C}$ for 48 hours with $150 \mathrm{rpm}$ agitation speed. The yeast and microbial inoculums were then used for biodegradation batch tests.

\subsection{Experimental Setup}

Aseptic inoculation was realized with microorganism seed culture prepared previously. Biodegradation tests were performed in batch into Erlenmeyer flasks $(500 \mathrm{ml})$ containing $150 \mathrm{ml}$ of the collected dairy wastewater samples. Two sets of experiments were carried out in duplicate. For the first set of experiments, the selected bacteria and yeast strains was added separately in the test samples with a concentration of $1 \%(\mathrm{v} / \mathrm{v})$ and incubated in the orbital shaker with a rotation speed of $150 \mathrm{rpm}$ at $30^{\circ} \mathrm{C}$ for 25 days. A blank experiment which consisted of noninoculated dairy wastewater sample was run in the same condition of the test samples. The COD measurement was carried out on aliquots samples at different intervals $(0,5$, $10,15,20$ and 25 days). For the second set of experiments, three inoculums rate $(1,5$ and $10 \%(\mathrm{v} / \mathrm{v}))$ were tested. A bacteria and yeast mixed culture was prepared by taking 1:1 bacteria strains and 1:1 yeast strains, respectively. Bacteria and yeast inoculums were added separately in the test samples and incubated in the orbital shaker with a rotation speed of $150 \mathrm{rpm}$ at $30^{\circ} \mathrm{C}$ for 25 days. Blank experiment which consisted of non-inoculated dairy wastewater sample was run in the same condition of the test samples. Aliquots of the samples were removed at different intervals $(0,5,10$, 15,20 and 25 days) and analyzed for the chemical oxygen demand (COD), proteins and total sugars. For the two sets of experiment, when the aliquots were removed from the samples for the analysis, a same volume of sterile deionised water was replaced to keep the concentration gradient constant and to compensate evaporation that could occur. Adjustment of $\mathrm{pH}$ (7-8) was done at the beginning of the tests. The chemical oxygen demand (COD) was measured using the $\mathrm{HACH}$ method $(25-1500 \mathrm{mg} / \mathrm{L}$ range) in COD vials (CSB-Kuvettentest, Merck, Darmstadt, Germany), which involves heating at $150^{\circ} \mathrm{C}$ during $2 \mathrm{hr}$ and then spectrophotometric reading. Total sugars were determined spectrophotometrically according to the method of Dubois [7] and the protein content was determined according to the method of Lowry [8] with bovine serum albumin (BSA, 1 $\mathrm{mg} / \mathrm{mL}$ ) as the protein standard. The protein content was determined by reading the absorbance at $600 \mathrm{~nm}$.

\section{RESULTS AND DISCUSSION}

\subsection{Characterization of Dairy Waste Water}

The influent characteristics of the dairy wastewater were analyzed periodically during three months and the average results are shown in Table 1 . In the present study, the $\mathrm{pH}$ mean value of the untreated effluent is very high as the incoming effluent is highly alkaline in nature. Mean values of chemical characteristics such as BOD, COD, chlorides, 
fatty material and suspended solids are $851.1 \mathrm{mg} / 1,1710.9$ $\mathrm{mg} / \mathrm{l}, 683.4 \mathrm{mg} / \mathrm{l}, 221.3 \mathrm{mg} / \mathrm{l}$ and $316.9 \mathrm{mg} / \mathrm{l}$, respectively. The higher standard variation confirms that the characteristics of dairy wastewater vary greatly within the industry. As it was reported in literature, dairy wastewater can be variable from factory to another according to the characteristics of milk and it is characterized by high concentrations of nutrients, organic and inorganic contents [9]. Significant variations in COD (80-95000 mg/l) and BOD (40-48000 $\mathrm{mg} / \mathrm{l}$ ) have been reported by various investigators of dairy wastewater [10]. The $\mathrm{pH}$ varies in the range of 4.7-11 whereas the concentration of suspended solids (SS) varies in the range of $0.024-4.5 \mathrm{~g} / 1$ [11].

Table -1: Characteristics of dairy wastewater

\begin{tabular}{|l|l|l|l|l|l|l|l|}
\hline & $\mathrm{pH}$ & $\begin{array}{l}\mathrm{EC} \\
(\mu \mathrm{s} / \mathrm{c} \\
\mathrm{m})\end{array}$ & $\begin{array}{l}\text { Chlori } \\
\mathrm{des} \\
(\mathrm{mg} / \mathrm{l})\end{array}$ & $\begin{array}{l}\mathrm{CO} \\
\mathrm{D} \\
(\mathrm{mg} / \\
1)\end{array}$ & $\begin{array}{l}\mathrm{BO} \\
\mathrm{D} \\
(\mathrm{mg} \\
/ \mathrm{l})\end{array}$ & $\begin{array}{l}\text { Fatty } \\
\text { mater } \\
\text { ial } \\
(\mathrm{mg} / \mathrm{l} \\
)\end{array}$ & $\begin{array}{l}\text { SS } \\
(\mathrm{mg} \\
/ \mathrm{l})\end{array}$ \\
\hline $\begin{array}{l}\text { Avera } \\
\text { ge } \\
\mathrm{n}=12\end{array}$ & $\begin{array}{l}10 . \\
6\end{array}$ & 3332 & 683.4 & $\begin{array}{l}171 \\
.7\end{array}$ & $\begin{array}{l}851 . \\
1\end{array}$ & 221.3 & $\begin{array}{l}316 . \\
9\end{array}$ \\
\hline $\begin{array}{l}\text { Stand } \\
\text { ard } \\
\text { deviat } \\
\text { ion }\end{array}$ & 1.1 & $\begin{array}{l}1383 \\
.2\end{array}$ & 358.5 & $\begin{array}{l}461 . \\
3\end{array}$ & $\begin{array}{l}255 . \\
0\end{array}$ & 121 & 99.4 \\
\hline
\end{tabular}

EC: electrical conductivity; COD: chemical oxygen demand; BOD: biological oxygen demand; SS: suspended solids

\subsection{Isolation and Identification of Strain}

In the present work, two morphotypes were obtained on CHROMagar TMCandida based on the color of the colonies: green and pink colonies. The two colonies were purified on Sabouraud Chloramphenicol agar and identified as Candida albicans and Candida krusei based on the morphological, microscopic, and biochemical characteristics. Two bacterial strains were purified on MRS agar and identified as Lactobacillus casei and Lactobacillus plantarum.

\subsection{Biodegradation Tests}

COD removal of microbial and yeast single cultures

During the first set of experiment, the samples inoculated with Candida albicans, Candida krusei, Lactobacillus casei and Lactobacillus plantarum were examined for their ability to reduce the chemical oxygen demand (COD). The initial COD of wastewater was found to be $1840 \mathrm{mg} / \mathrm{l}$, the COD removal rate was examined at $(5,10,15,20$ and 25 days) and the results are given in Figure1. It was observed that due to the inoculation of additional bacteria and yeast in the samples, there was an appreciable COD reduction after 15 days, the COD reduction was comparatively higher in the samples inoculated with Lactobacillus casei, Lactobacillus plantarum and Candida albicans with COD reduction up to $48 \%$.
It was also observed that after 20 days, the percentage of COD reduction remained unchanged. This was probably due to the fact that the substrate became a restricting factor or the microbial population grew reduced. In the present study, Lactobacillus plantarum showed the best reduction efficiency $(71 \%)$ of the effluent, whereas, Candida krusei showed least reduction (51\%) when compared to control $(53 \%)$ where only indigenous microflora were active (Figure2). Our results are in accordance with the reduction in COD seen by Golalikhani and Razavi [12] who used six Lactobacillus strains (L. plantarum, L. casei, L. acidophilus, L. rhamnosus, L. helveticus) to check their efficiency in reducing COD parameter from dairy effluent. The authors had reported that L. plantarum was the best organism studied to restore dairy wastewater. This phenotypic trait has uptake systems for peptides such as oligopeptide permease and dipeptide permease, which are the primary protein degradation products.

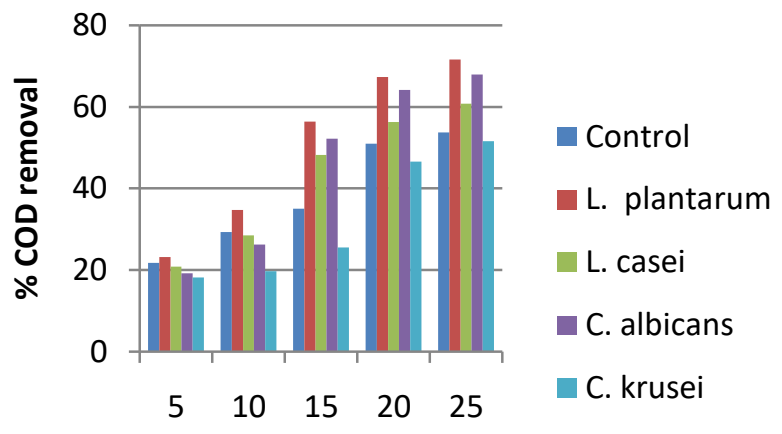

Time in days

Fig-1: Variation of COD removal rate by single culture during 25 days



Fig-2: COD removal rate by single cultures after 25 days at $1 \%(\mathrm{v} / \mathrm{v})$ inoculums rate

According to the literature, the most obvious difference between L. plantarum and other Lactobacillus strains is the number of peptidases capable for cleaving $\mathrm{N}$-terminal proline residues because this organism has three such genes whereas the others have none [13]. Performance of bacteria single cultures in COD removal is subject to variations in the literature; the COD reduction up to 87.5 and $75 \%$, 
respectively, by Bacillus subtilis immobilized in sawdust and sodium alginate after 20 days [9]. A significant reduction of COD (up to 90\%) using Pseudomonas fluorescens was found by Rajeshkumar and Jayachandran [14] during treatment of sweet whey after 20 days. Chatterjee and Pugaht [15] had also reported $67.1 \%$ and $48.3 \%$ reduction in COD of dairy wastewater with use of two bacterial strains namely Neisseria sp. and Citrobacter sp. The bacteria strains (Pseudomonas sp., Serratia sp., Staphylococcus sp., Bacillus sp., Micrococcus sp.) isolated by Saxena et al. [16] were found to have a good potential to biodegrade the effluent generated from dairy industry and was able to reduce COD load up to $76 \%$ with $1 \%$ inoculums at 20 days. Golalikhani and Razavi [12] reported a COD removal efficiency of $79 \%$ for Lactobacillus plantarum under the optimum condition. The most important approaches for achieving high effectiveness of dairy wastewater treatment process are both acclimation and immobilization of biomass [9]. It is increasingly being felt that using bioaugmentative microorganisms from the same ecological niche is advantageous as they are physiologically adapted to their environment and also have the ability to work in synchrony with the indigenous microflora [17]. In the case of yeast strains in degrading organic matter of dairy wastewaters, the values of the removal efficiency of COD observed in the present study are in concordance with those reported in the literature; the COD reduction by Candida albicans and Candida krusei were, respectively, 67 and 51\% after 25 days. According to Modgil et al. [18], the organic matter was reduced by various yeast spp; C. versatilis (82\%), C. haemulonii (74\%), C. parapsilosis (81\%). The COD has been receiving reduction up to 50 and $75 \%$ using Candida albicans immobilized in sawdust and sodium alginate after 20 and 15 days, respectively [9].

\section{Removal Efficacy of Microbial and Yeast Mixed Culture}

As was shown in the first set of experiment, at 20 and 25 days of incubation period, the percentage of COD removal rate remains unchanged. The same applies to what was observed for yeast and bacteria consortium. According to Garcha et al. [17], the population of added microbes declined with increased incubation time, it may be due to various reasons such as substrate requirement and qualitative content of microbial population, which necessitates their periodic addition to maintain the population which is affected by many factors such as physiological conditions of the effluent. The results of this study indicated that the COD removal by mixture culture of Lactobacillus plantarum and Lactobacillus casei is higher than the other treatment. Bacteria consortium exhibited maximum COD reduction of $86.3 \%$ in the dairy effluent of neutral $\mathrm{pH}$ with an inoculum level of $5 \%(\mathrm{v} / \mathrm{v})$, however, yeast consortium exhibited maximum COD reduction of $78.5 \%$ with an inoculums level of $5 \%(\mathrm{v} / \mathrm{v})$. The results obtained by Saxena et al. [16] showed that bacterial strains isolated from dairy wastewater and inoculated with different concentration $(0.1 \%, 0.5 \%, 1 \%)$ were effective in reducing the level of COD with a maximum COD reduction occurring at $1 \%$ inoculums rate. The comparison of the COD removal efficiency of single strains to mixed culture shows that, in the present study, the COD was reduced to $75.8 \%$ with bacterial consortium with an inoculums rate of $1 \%$, however, the reduction efficiency of single cultures were $71.6 \%$ and $60.8 \%$, respectively, for Lactobacillus plantarum and Lactobacillus casei at the same inoculums rate $(1 \%$ $(\mathrm{v} / \mathrm{v}))$. Porwal et al. [6] reported that a mixed culture of bacteria and yeast isolates has the best reduction efficiency of the effluent than single cultures with COD reduction rate of $86 \%, 73 \%$ and $66 \%$, respectively, for mixed culture, yeast isolate and bacteria isolate. Chatterjee and Pugaht [15] had also reported $67.1 \%$ and $48.3 \%$ reduction in COD of dairy wastewater using a mixed culture with the use of two bacterial strains namely Neisseria sp. and Citrobacter sp. The results obtained by Saxena et al. [16] revealed that a mixed culture of bacterial strains (Pseudomonas sp., Serratia sp., Staphylococcus sp., Bacillus sp.) have the ability to reduce the $\mathrm{COD}$ value up to $76 \%$, however, the COD removal of bacterial single cultures showed lower values. In the case of yeast ability to reduce organic matter, Sathya Pria et al. [19] reported that the COD parameter was reduced to $81.7 \%, 83.7 \%$ and $90.7 \%$, respectively, by Streptomyces indiaensis, Streptomyces hygroscopicus and mixed consortium of Streptomyces.

Figures 3 and 4 show percentage reduction of total sugar and protein after 25 days by bacteria and yeast consortiums as compared to control.

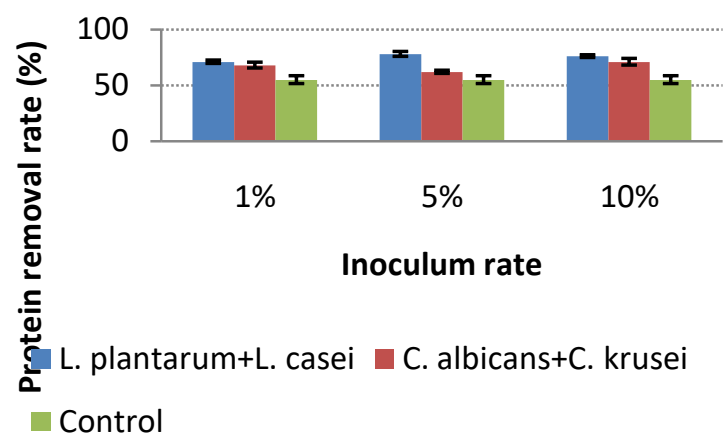

Fig-3: Proteins removal by mixed culture after 25 days incubation period at different inoculums rate

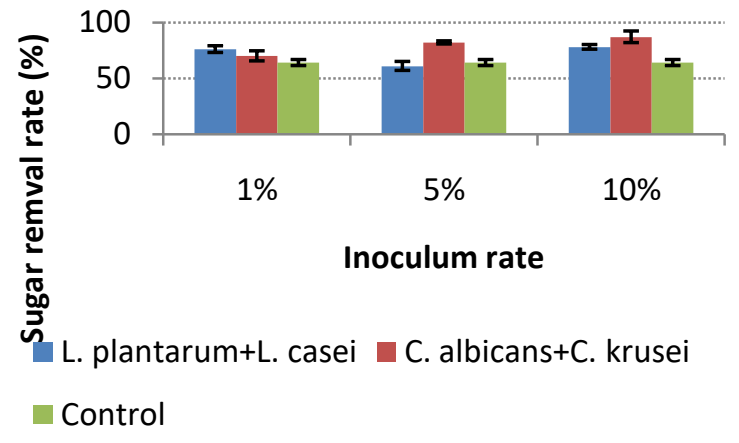

Fig-4: Sugar removal by mixed culture after 25 days incubation period at different inoculums rate 
The highest reduction of total sugar content was obtained by yeast consortium 87 and $82 \%$, respectively, with 10 and $5 \%$ inoculums rate. On the other hand, the highest reduction of protein content was obtained by bacteria consortium 78 and $76 \%$, respectively, with 5 and $10 \%$ inoculums rate. A Similar observation attributing the highest reduction of total sugar was found by immobilized Candida albicans and the highest reduction of protein was found by immobilized Bacillus subtilis [9]. Livingston et al. [20] stated that the Bacillus strains removed protein content of dairy wastewater in the range of $60-90 \%$ because of the high enzymatic proteolytic activity, generally found in the genus Bacillus.

\section{CONCLUSION}

In the present study, the bacterial isolates from untreated wastewater were used for the treatment of dairy wastewater. The identification of microorganisms isolated from activated sludge pond is shown to be Candida albicans, Candida krusei, Lactobacillus plantarum and Lactobacillus casei. Two consortia were constructed from individual strains: bacteria and yeast mixed culture. As far as COD Reduction is concerned, the results showed that isolated bacteria strain have the ability to reduce the COD value up to $71.6 \%$. Best results were obtained in bacteria consortia which reduce the COD up to $81 \%$. Addition of $5 \%(\mathrm{v} / \mathrm{v})$ of inoculum gave the best biodegradation rate compared to 1 and $10 \%(\mathrm{v} / \mathrm{v})$. However, a mixed culture would prove to be more effective and beneficial than a single culture. The microorganisms isolated from Tunisian dairy plant can be efficiently applied for the biological treatment of the dairy effluent treatments. This study offers preliminary data identifying some new active strains adapted to the dairy wastewater physical chemical conditions with a maximum COD removal rate of $82 \%$ with a use of bacterial mixed culture, this efficiency could be improved with supplemented tests aiming to optimize physical conditions of bacteria development.

\section{ACKNOWLEDGEMENT}

The authors would like to express their gratitude to $\mathrm{Mr}$ Wassim Hariz from the English Language Unit at the Faculty of Science, Sfax, Tunisia for their proofreading and language polishing services

\section{REFERENCES}

[1] Montuelle B J, Coillard M $\square$ Lehy J B, 1992. A combined anaerobic aerobic process for the cotreatment of effluents from a piggery and a cheese factory, J Agri Eng Res, 51: 91-100.

[2] Djelal H, Perrot M $\square$ Grisard D, 2007 Utilisation de champignons spécifiques pour la biodégradation d'effluents industriels, L'Eau, l'Industrie et les Nuisances, $306: 85-91$, in french.

[3] Shivsharan V S, Wani M $\square$ Khetmalas M B, 2013. Isolation of Microorganisms from Dairy Effluent, British Microbiology Research Journal, 3 (3): 346354.

[4] APHA (American Public Health Association), 2005. Standard Method for the Examination of Water and
Wastwater, 20th edition, Water Environment Federation, Washington, D.C., USA.

[5] Samet-Bali O, Ennouri M, Dhouib A $\square$ Attia H 2012. Characterisation of typical Tunisian fermented milk: Leben. African journal of microbiological Research, 6 (9): 2169-2175.

[6] Porwal H J, Mane A V $\square$ Velhal S G, 2015. Biodegradation of dairy effluent by using microbial isolates obtained from activated sludge, Water Resources and Industry, 9: 1-15

[7] Dubois M, Gilles K A, Hamilton J K, Rebers P A $\square$ Smith F, 1956. Colorimetric method for determination of sugars and related substances, Analyt Chem, 28: 350-356.

[8] Lowry O H, Rosebrough N J, Farr A L $\square$ Randall R J, 1951. Protein measurement with the folin phenol reagent, J. Biol Chem, 193:75-265.

[9] Mostafa Azza A, 2013. Treatment of Cheese Processing Wastewater by Physicochemical and Biological Methods, International Journal of Microbiological Research, 4 (3):321-332.

[10] Jaiprakash K, Srivastava V C $\square$ Mall I D, 2011. An overview of various technologies for treatment of dairy wastewaters, Critical Review in Food Science and Nutrition, 511: 442-452.

[11] Passeggi M, Lopez I $\square$ Borzacconi L, 2009. Integrated anaerobic treatment of dairy industrial wastewater and sludge, Water Sci Technol, 59: 501506.

[12] Golalikhani M Razavi S H, 2015. An Efficient Biological Treatment on Dairy Wastewater by Lactobacillus plantarum: Mathematical Modeling and Process Parameters Optimization, Int J Food Eng, DOI 10.1515/ijfe-2015-0109.

[13] [Kleerebezem M, Boekhorst J, Van Kranenburg R, Molenaar D, Kuipers O P $\square$ Leer R, 2003. Complete genome sequence of Lactobacillus plantarum WCFS1, Proc. Nat. Acad. Sci, U S A, 100: 19901995.

[14] Rajeshkumar K $\square$ Jayachandran K, 2004. Treatment of dairy wastewater using a selected bacterial isolate, Alcaligenes sp. MMRR7, Applied Biochemistry and Biotechnology, 118: 65-72.

[15] Chatterjee S $\square$ Pugaht P, 2013. Assessment of physico-chemical parameters of dairy wastewater and isolation and characterization of bacterial strains in terms of COD reduction, International Journal of Science Enviro Technol, 2: 395-400.

[16] Saxena S, Sharma N $\square$ Saksham Gupta A D, 2015. Isolation and Characterization of Bacterial Strains In Terms Of COD Reduction from Dairy Wastewater, Journal of Environmental Science Computer Science Engineering \& Technology, Sec. A, 4 (2): 319-328.

[17] Garcha S, Brar S K $\square$ Sharma K, 2014. Performance of a laboratory prepared microbial consortium for degradation of dairy wastewater in batch system, Journal of scientific and industrial Research, 73: 346350 .

[18] Modgil A, Garcha S, Bansal M, Kaur K, Dhammi M Kaur H, 2009. Potential of yeast in biological 
treatment of dairy effluents, Indian J Dairy Sci, 62: 151-154.

[19] Sathya Priya B, Stalin T $\square$ Selvam K, 2014. Ecosafe bioremediation of dairy industry effluent using Streptomyces indiaensis ACT 7 and Streptomyces hygroscopicus ACT 14 and application for seed germination of Vigna radiate, African Journal of Microbiology Research, 8 (23) : 2286-2289.

[20] Livingston P G, Saseetharan M K, Jeyanthi J \& Begum N N, 2013. Experimental study on biodegradation of dairy wastewater using bacterial isolate, Journal of environmental science and engineering, 55(4): 472-480. 